Article

\title{
Corrosion Behavior of a Pyrite and Arsenopyrite Galvanic Pair in the Presence of Sulfuric Acid, Ferric Ions and HQ0211 Bacterial Strain
}

\author{
Jia-Ning $\mathrm{Xu}{ }^{1, *}$, Wen-Ge Shi ${ }^{2}$, Peng-Cheng Ma ${ }^{2}$, Liang-Shan Lu ${ }^{2}$, Gui-Min Chen ${ }^{3}$ and \\ Hong-Ying Yang ${ }^{1, *}$ \\ 1 School of Metallurgy, Northeastern University, Wenhua Road NO. 3-11, Heping District, \\ Shenyang 100819, China \\ 2 Shandong Zhaojin Group Co., Ltd., Shengtai Road NO. 108, Zhaoyuan 265400, China; \\ 13853566318@163.com (W.-G.S.); aust.pengcheng@163.com (P.-C.M.); jcllls@126.com (L.-S.L.) \\ 3 Hainan Shanjin Mining Co., Ltd., Ledong 572500, China; tongtong4858@163.com \\ * Correspondence: xuyaoiii@163.com (J.-N.X.); yanghy@smm.neu.edu.cn (H.-Y.Y.); \\ Tel.: +86-024-8367-3932 (H.-Y.Y.)
}

Received: 4 January 2019; Accepted: 1 March 2019; Published: 9 March 2019

\begin{abstract}
In this paper, the galvanic effect of pyrite and arsenopyrite during the leaching pretreatment of gold ores was determined with the use of electrochemical testing (open circuit potential, linear sweep voltammetry, Tafel, and electrochemical impedance spectroscopy (EIS)) and frontier orbit calculations. The results show that (i) the linear sweep voltammetry curve and Tafel curve of the galvanic pair are similar to those of arsenopyrite, (ii) the corrosion behavior of the galvanic pair is consistent with that of arsenopyrite, and (iii) the galvanic effect promotes the corrosion of arsenopyrite by simultaneously increasing the cathode and anode currents and reducing oxidation resistance. The frontier orbit calculation explains the principle of the galvanic effect of pyrite and arsenopyrite from the view of quantum mechanics.
\end{abstract}

Keywords: galvanic effect; pyrite-arsenopyrite galvanic pair; electrochemical; frontier orbital methods

\section{Introduction}

The chemical formulas of pyrite and arsenopyrite are $\mathrm{FeS}_{2}$ and FeAsS, respectively. Pyrite and arsenopyrite are the two most important gold-containing minerals in gold ores [1-4]. Fine-grained or submicroscopic gold is disseminated within pyrite and arsenopyrite, thereby rendering gold inaccessible to cyanide solutions [5]. Dissolving pyrite and arsenopyrite is the main objective of the biological pretreatment of gold ores [6-8]. Arsenic present in arsenopyrite is harmful to the bacteria used in bioleaching. A decision whether to leach run-of-mine ore or concentrate can only be made after determining the percentage of gold which is trapped in both sulfides and the free gold as well, to minimize the operating cost of the process [5]. In the case where gold is preferentially associated with arsenopyrite, only partial oxidation of this arsenopyrite is required for an increased gold liberation [9]. The oxidation reactions of pyrite and arsenopyrite during bioleaching have been widely discussed. Komnitsas et al. [5,9] and Smith et al. [10] described the aqueous oxidation of pyrite using stoichiometric chemical reactions:

$$
\mathrm{FeS}_{2}+\frac{7}{2} \mathrm{O}_{2}+\mathrm{H}_{2} \mathrm{O} \rightarrow \mathrm{Fe}^{2+}+2 \mathrm{SO}_{4}^{2-}+2 \mathrm{H}^{+}
$$




$$
\begin{gathered}
\mathrm{Fe}^{2+}+\frac{1}{4} \mathrm{O}_{2}+\mathrm{H}^{+} \rightarrow \mathrm{Fe}^{3+}+\frac{1}{2} \mathrm{H}_{2} \mathrm{O} \\
\mathrm{FeS}_{2}+14 \mathrm{Fe}^{3+}+8 \mathrm{H}_{2} \mathrm{O} \rightarrow 15 \mathrm{Fe}^{2+}+2 \mathrm{SO}_{4}^{2-}+16 \mathrm{H}^{+} \\
\mathrm{FeS}_{2}+6 \mathrm{Fe}^{3+}+3 \mathrm{H}_{2} \mathrm{O} \rightarrow 7 \mathrm{Fe}^{2+}+\mathrm{S}_{2} \mathrm{O}_{3}^{2-}+6 \mathrm{H}^{+} \\
\mathrm{S}_{2} \mathrm{O}_{3}^{2-}+8 \mathrm{Fe}^{3+}+5 \mathrm{H}_{2} \mathrm{O} \rightarrow 8 \mathrm{Fe}^{2+}+2 \mathrm{SO}_{4}^{2-}+10 \mathrm{H}^{+}
\end{gathered}
$$

The reactions involved in the aqueous oxidation of arsenopyrite are shown in Equations (6) and (7) [11,12]:

$$
\begin{gathered}
\mathrm{FeAsS}+8 \mathrm{Fe}^{3+}+(4+n) \mathrm{H}_{2} \mathrm{O} \rightarrow \mathrm{FeAsO}_{4}\left(n \mathrm{H}_{2} \mathrm{O}\right)+8 \mathrm{Fe}^{2+}+\mathrm{S}_{(\text {surface })}^{0}+8 \mathrm{H}^{+} \\
4 \mathrm{FeAsS}+11 \mathrm{O}_{2}+6 \mathrm{H}_{2} \mathrm{O} \rightarrow 4 \mathrm{Fe}^{2+}+4 \mathrm{H}_{3} \mathrm{AsO}_{3}+4 \mathrm{SO}_{4}^{2-}
\end{gathered}
$$

The role of ferric ions, which are produced by the bacterial oxidation of ferrous ions, accelerates oxidation of sulfide phases and raises solution Eh [9]. In fact, ferric ions can be regarded as "catalysts" for the reactions involved in the oxidation of minerals. Ferrous ions are oxidized to ferric ions by oxygen, which then oxidizes minerals and produces more ferrous ions in a perpetual process which can be significantly accelerated by bacteria. Bioleaching takes place in an acidic solution, and the hydrogen ions are either the reactants or products of the bioleaching reaction. In a ferric ion solution $(\mathrm{pH}<4)$, the oxidants of pyrite and arsenopyrite are ferric ions, rather than dissolved oxygen [12,13]. Thus, the galvanic effect of pyrite/arsenopyrite in the presence of sulfuric acid, ferric ion, and HQ0211 bacteria strain solutions was assessed in this paper.

Biological pretreatment of gold ores is associated with galvanic effects [14-16]. The oxidation potential of pyrite is around $630 \mathrm{mV}$, while arsenopyrite oxidation is initiated at much lower Eh values, ranging between 390 and $430 \mathrm{mV}[5,9]$. The rest potential of arsenopyrite is lower than that of pyrite. Under acidic conditions, a galvanic effect occurs when they contact each other, after which arsenopyrite dissolves as an anode, and pyrite acts as a cathode [17,18]. In addition, it is well known that the galvanic effect promotes the corrosion of arsenopyrite in the process of arsenical gold sulfide concentrate bio-pretreatment. In other words, the presence of pyrite accelerates oxidation of arsenopyrite [5-9]. In recent years, the galvanic mechanism of pyrite and arsenopyrite in different media has been discussed [14-18]. Urbano et al. [15] stated that the electrochemical reactivity of pyrite in contact with arsenopyrite mineral was delayed and shifted to more positive potentials with respect to the high-purity pyrite mineral electrochemical response due to the galvanic effect. This reaction process was described according to the results of scanning electron microscopy (in ferric-free solution with a $\mathrm{pH}$ of 6.5). Santos et al. [17] calculated the stability, structure, and electronic properties of the pyrite/arsenopyrite solid-solid interface by DFT (density functional theory) and stated that the valence band of the pyrite/arsenopyrite interface has large contributions from the pyrite phase, while the conduction band has large contributions from the arsenopyrite. This is consistent with the role of pyrite as the cathode and arsenopyrite as the anode in galvanic contact with unfavorable miscibility. Deng et al. [18] studied the galvanic pair in a $9 \mathrm{~K}$ culture medium and sulfuric acid ( $\mathrm{pH}=1.6)$, which revealed that the presence of pyrite increased the conductivity of the electrodes and electrolytes. Thus, this verified the catalytic effect of the galvanic interactions on the process of arsenopyrite leaching. In addition, the galvanic effect of other minerals has also been studied, such as pyrite/chalcopyrite [14], chalcopyrite/magnetite [16], pyrite/gold [19], and pyrite/galena [20]. Pyrite and arsenopyrite are contained in almost all types of gold ores, as they make contact naturally and form a galvanic pair during leaching. In the bioleaching process, the effective components in the solution are sulfuric acid, ferric ions, and the bio-leaching bacteria. However, the promoting mechanism of the galvanic effect of pyrite and arsenopyrite in the leaching process has been seldom discussed. The novelty of this paper is the study of the corrosion behavior of pyrite, arsenopyrite, and the galvanic pair in the presence of 
sulfuric acid, ferric ions, and the HQ0211 strain (a mixture of strains protected by a patent in our lab) by electrochemical methods.

The study is an in-depth attempt to interprete by means of electrochemical measurements and DFT calculations a well-known phenomenon of practical importance for gold ore pretreatment: the galvanic corrosion of arsenopyrite in contact with pyrite. The electrochemical corrosion behavior of pyrite, arsenopyrite, and galvanic pairs is compared in detail. The electrochemical impedance spectroscopy (EIS) models of pyrite/arsenopyrite galvanic pair are established and explained. Furthermore, an EIS model of arsenopyrite oxidation with less fitting error (absence of ferric ions, $\mathrm{pH}=1.5$ ) is proposed. The mechanism of galvanic effect accelerating arsenopyrite corrosion is discussed. Then the electrokinetic properties of pyrite and arsenopyrite are calculated according to the frontier orbital theory based on the density functional theory (DFT) which provided a quantum mechanics perspective of pyrite/arsenopyrite galvanic effect.

\section{Experimental Methods}

\subsection{Electrochemical Methods}

The pyrite and arsenopyrite specimens were obtained from Shandong Zhaojin Group Co., Ltd., Zhaoyuan, China. The results of X-ray diffraction (XRD) analysis (model of the instrument: D8 ADVANCE; wavelength radiation: 1.5405 Angstrom; $\mathrm{kV}$ and $\mathrm{mA}$ values during operation: $30 \mathrm{KV}$ and $40 \mathrm{~mA}$; type of detector: LYNXEYE, Bruker Corporation, Billerica, MA, USA) of the pyrite and arsenopyrite are shown in Figure 1. To avoid the influence of mineral oxidation on electrochemical behavior during grinding, block electrodes were used in all electrochemical experiments instead of carbon paste electrodes. The specimens were cut into rectangular slices with dimensions of approximately $10 \times 10 \times 5 \mathrm{~mm}$ and mounted using epoxy resin. The slides were polished on both sides. An insulated copper wire was attached to the underside of the specimen using silver conductive epoxy, which was subsequently coated with epoxy resin. A fresh pyrite surface was created before each experiment by abrading with successively finer grades $(600,800,1200,1600$, and 2000 grit) of silicon carbide paper, which was followed by successive polishing with 3,1 , and $0.5 \mu \mathrm{m}$ diamond suspensions and rinsing with Milli-Q water in a nitrogen-filled vessel for $20 \mathrm{~s}$. The exposed surfaces of pyrite, arsenopyrite, and the pyrite-arsenopyrite galvanic pair electrode are shown in Figure 2a-c, respectively. Milli-Q water with a specific resistance of $18.2 \mathrm{M} \Omega \cdot \mathrm{cm}^{-1}$ was used in all experiments, and all reagents used in this study were of analytical purity. The sulfuric acid solution $(\mathrm{pH}=1.5)$ and ferric sulfate solution $\left(\mathrm{pH}=1.5,9 \mathrm{~g} \cdot \mathrm{L}^{-1} \mathrm{Fe}^{3+}\right)$ were prepared from sulfuric acid and ferric sulfate. The HQ0211 bacteria strain was obtained (solution potential $>600 \mathrm{mV}$, number of viable bacteria $>10^{7} / \mathrm{mL}, \mathrm{pH}=1.5$ ) and $0.01 \mathrm{~mol} / \mathrm{L} \mathrm{Na}_{2} \mathrm{SO}_{4}$ was used as the supporting electrolyte in all electrochemical solutions. All electrochemical experiments were conducted on a CHI660e electrochemical workstation, (CH Instruments, Inc., Austin, TX, USA). Electrochemical measurements were performed using a conventional three-electrode system. The experimental conditions of the open circuit potential test (Table 1), linear sweep voltammetry test (Figure 4), polarization curve test (Figure 4), and AC impedance test (Figure 5) are shown in the annotations of the figures of each test. To simulate a real leaching environment, the dissolved oxygen in the solution was not removed during the experiment. All potential values in this paper are relative to a standard hydrogen electrode (SHE). 


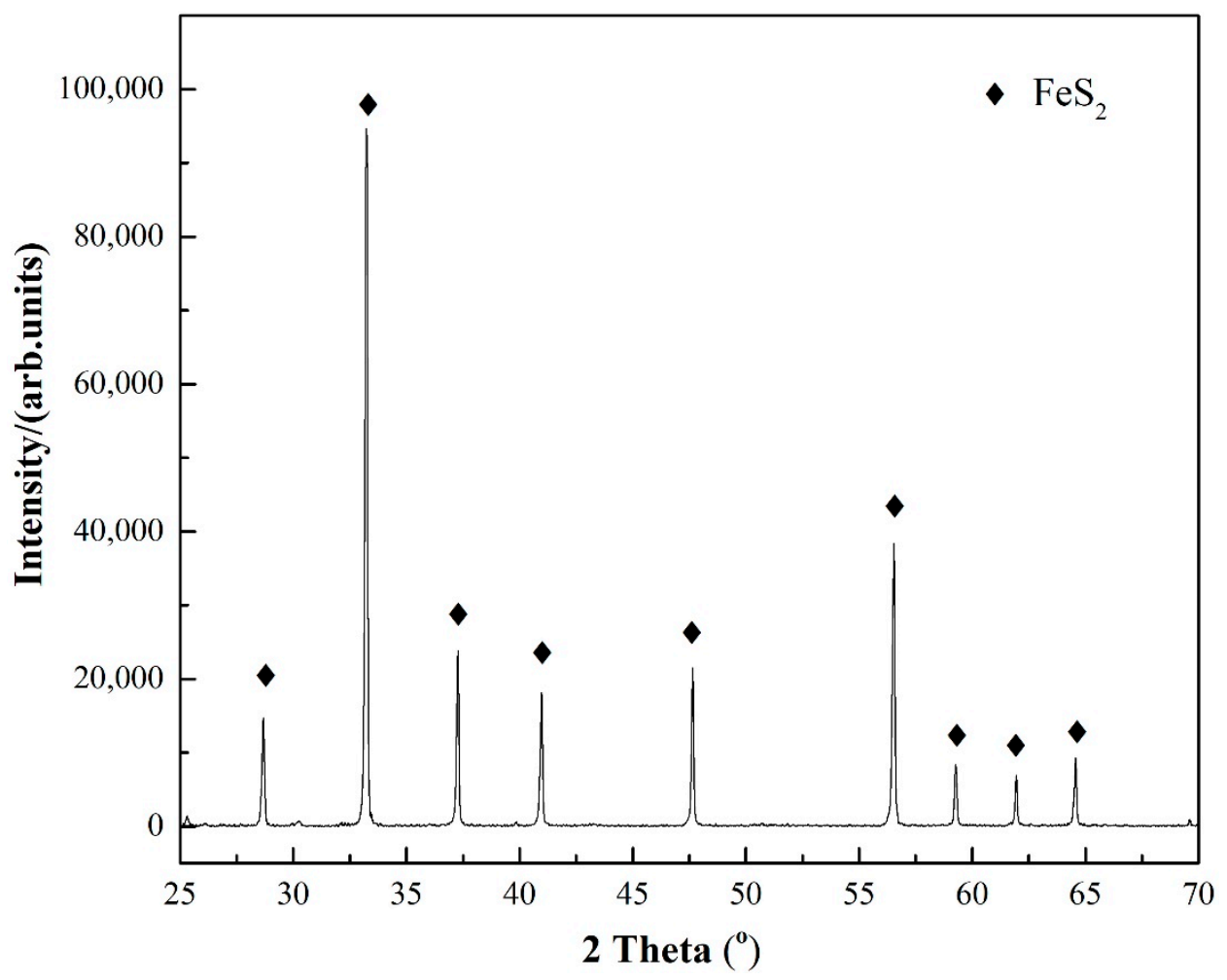

(a)

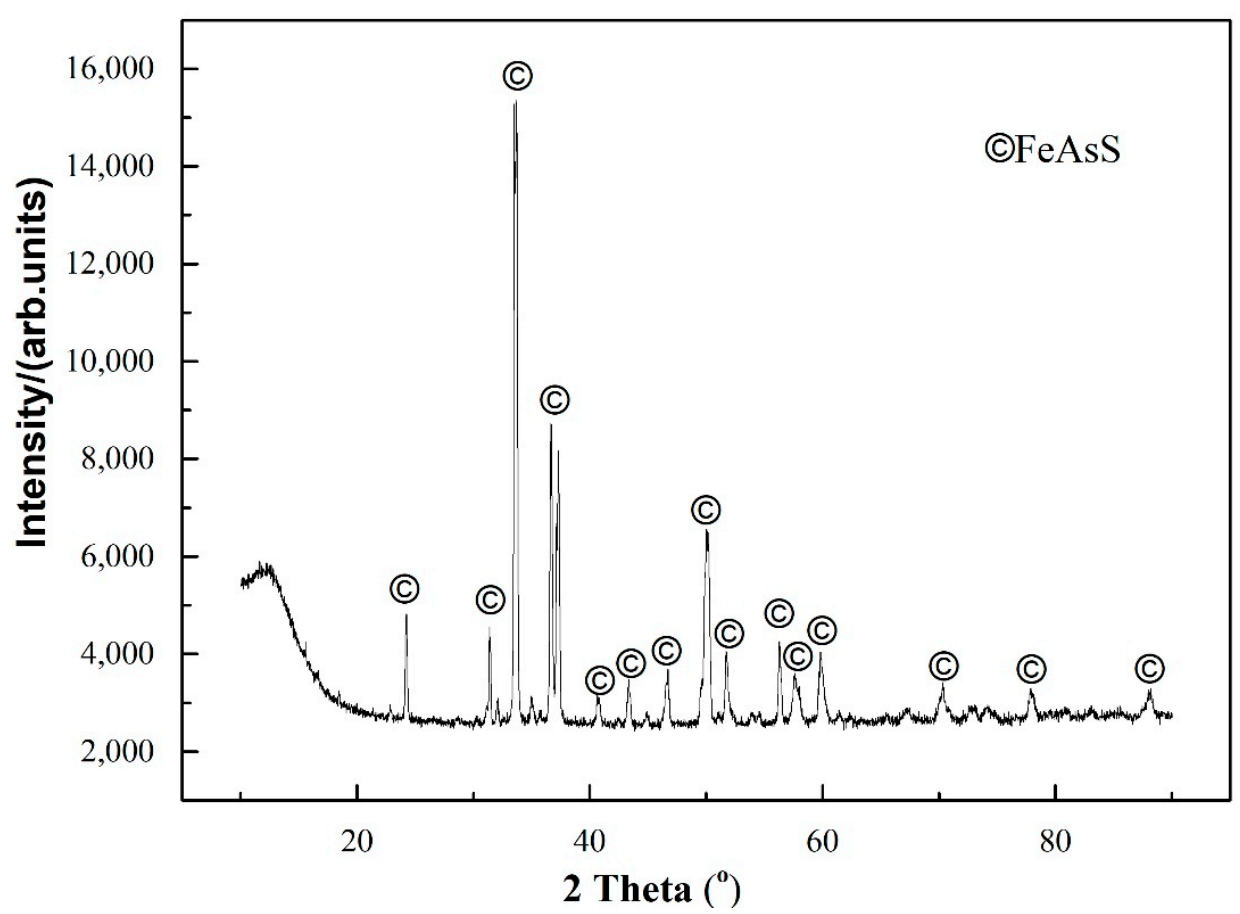

(b)

Figure 1. X-ray diffraction (XRD) patterns of pyrite (a) and arsenopyrite (b). 


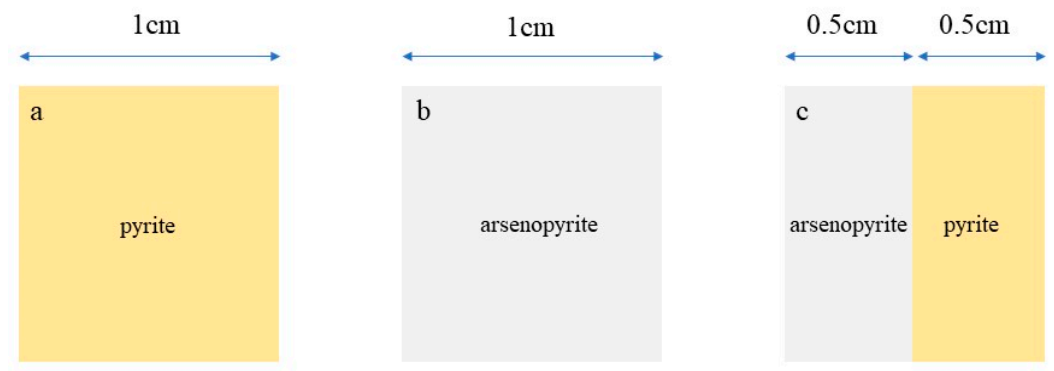

Figure 2. The exposed surfaces of pyrite (a), arsenopyrite (b), and the pyrite-arsenopyrite galvanic pair electrode (c).

Table 1. The mean open circuit potentials (OCPs) of pyrite, arsenopyrite, and the galvanic pair in the investigated solutions.

\begin{tabular}{cccc}
\hline Solution Type & Pyrite $(\mathbf{m V})$ & Arsenopyrite $\mathbf{( m V )}$ & Galvanic Pair $(\mathbf{m V})$ \\
\hline Sulfuric acid & 704 & 316 & 354 \\
Ferric ion & 729 & 435 & 479 \\
HQ0211 strain & 768 & 446 & 614 \\
\hline
\end{tabular}

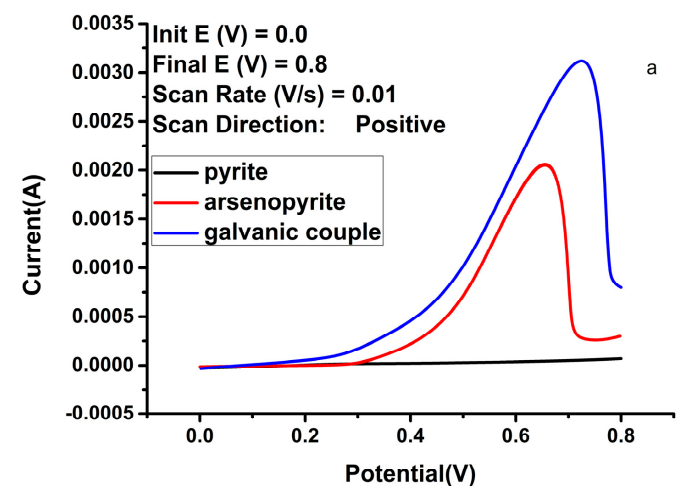

(a)

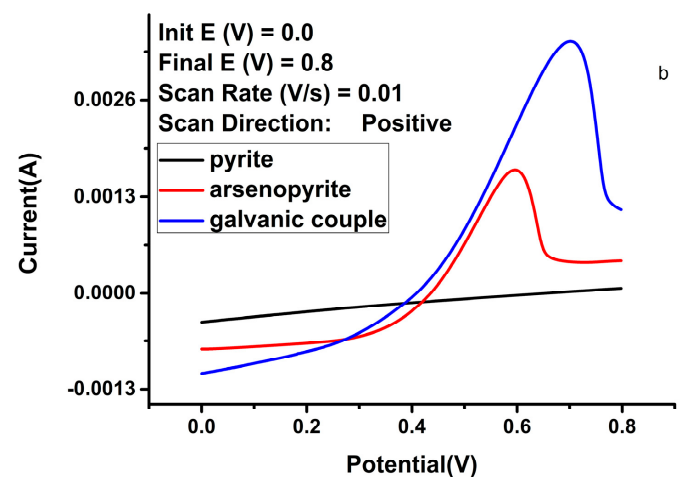

(b)

Figure 3. Cont. 


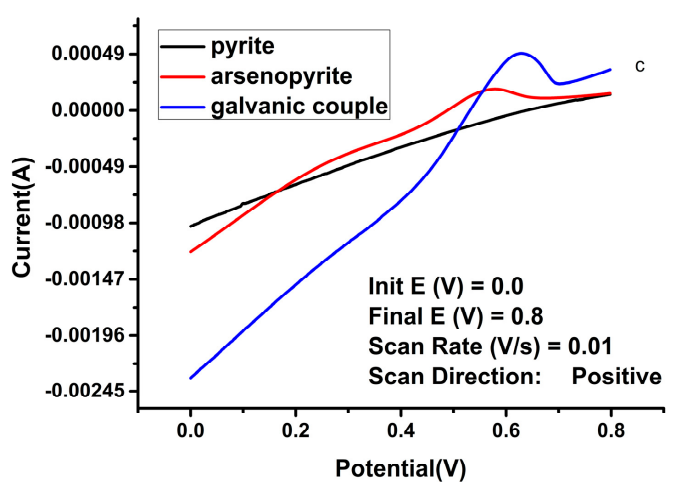

(c)

Figure 3. Linear sweep voltammetry curves of the three investigated electrodes in sulfuric acid (a), ferric ion (b), and HQ0211 strain solutions (c) (Init E: Initial potential of linear sweep voltammetry test, Final E: Final potential of linear sweep voltammetry test).

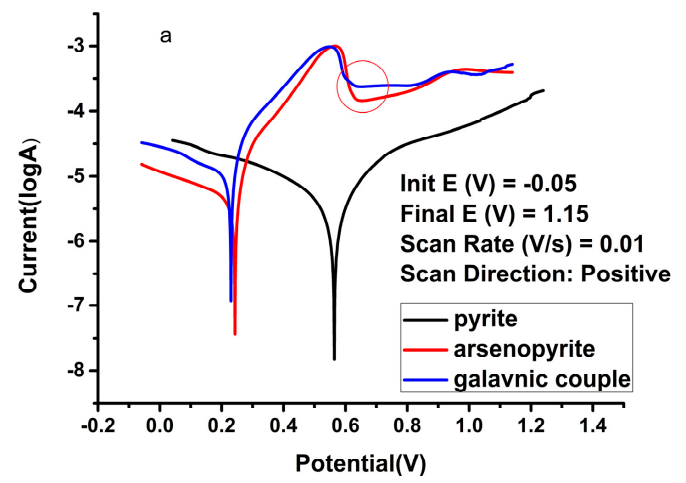

(a)

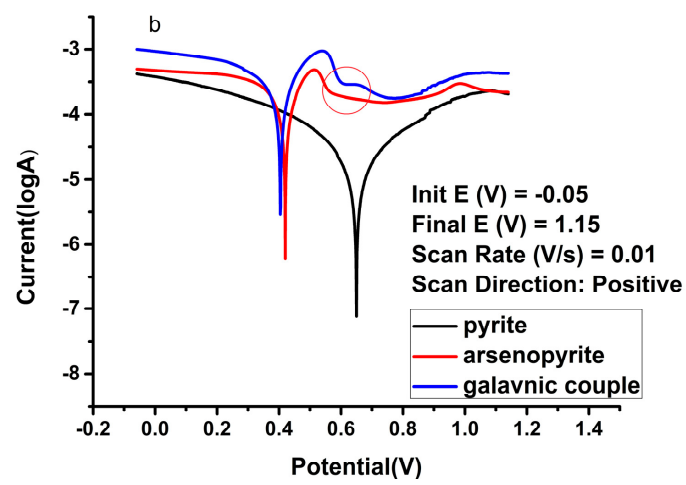

(b)

Figure 4. Cont. 


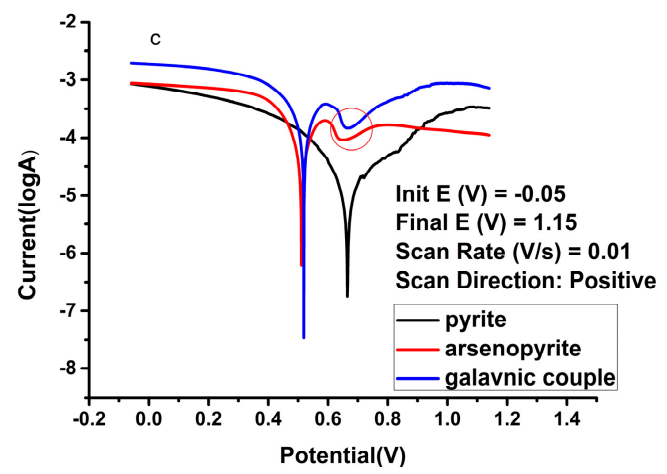

(c)

Figure 4. Tafel curves of the three investigated electrodes in sulfuric acid (a), ferric ion (b), and HQ0211 strain solutions $(\mathbf{c})$.

\subsection{DFT Calculational Details}

All calculations were performed using DMOL3 (Version: 5.0, Accelrys, San Diego, CA, USA) [21] and the generalized gradient approximation (GGA) PW91 density functional [22]. Only the valence electrons ( $\mathrm{Fe} 3 \mathrm{~d}^{6} 4 \mathrm{~s}^{2}$ and $\mathrm{S} 3 \mathrm{~s}^{2} 3 \mathrm{p}^{4}$ As $4 \mathrm{~s}^{2} 4 \mathrm{p}^{3}$ ) were considered by using ultra soft pseudopotentials [23] and a plane wave cut-off energy of $300 \mathrm{eV}$ after testing. The Monkhorst-Pack $k$-point sampling density for pyrite was $4 \times 4 \times 4$ for a mesh and $2 \times 3 \times 2$ for arsenopyrite. The self-consistent field (SCF) convergence tolerance was set to $1.0 \times 10^{-6} \mathrm{eV} \cdot$ atom $^{-1}$. Because of the existence of iron atoms in pyrite and arsenopyrite, the electron spin polarization was considered in calculations.

Pyrite (cubic symmetry) with a space group Pa-3 and cell parameter of $5.417 \AA$ [24], and arsenopyrite with a space group B-1 $\left(a=9.51 \AA ; b=5.65 \AA\right.$; $\left.c=6.42 \AA ; \alpha=\beta=\gamma=90^{\circ}\right)$ were used in our calculations [25].

\section{Results and Discussion}

\subsection{Surface Activity}

Galvanic interaction is closely related to the surface activity of two electrically connected materials [18]. The surface activity of pyrite and arsenopyrite in a solution was tested via open circuit potential (OCP) testing. The mean OCPs of pyrite, arsenopyrite, and the galvanic pair in a solution are listed in Table 1.

Due to the adsorption of ferric ions and bacteria onto the mineral surface and the previously mentioned oxidation reactions, the OCPs of pyrite and galvanic pair in the sulfuric acid, ferric ion, and HQ0211 strain solutions increased successively. The pyrite OCP value in HQ0211 strain is higher than that in the ferric ion solution. Ferric iron is produced by the oxidation of ferrous iron (reaction (3)) while the action of bacteria produces more ferric iron [9]. The mechanism of the enrichment of mineral surfaces with ferric ions produced by bacterial action has been mainly discussed elsewhere [26,27]. Due to the toxicity of arsenopyrite to bacteria, the OCP of arsenopyrite in the bacterial solution is only slightly higher ( $435 \mathrm{mV}$ to $446 \mathrm{mV}$ ) than that in the ferric ion solution [28-30].

Pyrite shows higher OCP values than arsenopyrite in the three tested solutions (Table 1), which indicates that it is more stable than arsenopyrite. Since the electrode potential determines the intrinsic polarity of a galvanic pair, pyrite with the higher OCP would serve as the cathode while arsenopyrite with the lower OCP would act as the anode. The galvanic potentials of the galvanic pair in a two-electrode system in the three tested solutions were $388 \mathrm{mV}, 294 \mathrm{mV}$, and $322 \mathrm{mV}$, respectively, meaning that the galvanic interaction between them truly exists.

Table 1 also shows that the OCP values of the galvanic pair were higher than those of arsenopyrite in all tested solutions. As the OCP of the galvanic pair reflects the new equilibrium point of pyrite and arsenopyrite, and the OCP of the galvanic pair is higher than the OCP of arsenopyrite, it can, therefore, 
polarize the arsenopyrite electrode positively and provide a positive over-potential to shift the overall reaction to the anodic region. This leads to an increase in the oxidation rate of arsenopyrite in all three solutions investigated in this paper.

\subsection{Dissolution Behavior of the Galvanic Pair}

Linear sweep voltammetry was performed to explain the dissolution process of the three electrodes. The linear sweep voltammetry curves of the three investigated electrodes in the three investigated solutions are shown in Figure 4. Compared with those of arsenopyrite and the galvanic pair, the oxidation peak of pyrite is insignificant in the three tested solutions, and the oxidation curve of arsenopyrite is similar to that of the galvanic pair. The results show that the oxidation behavior of the galvanic pair is similar to that of arsenopyrite within the sweep range, in agreement with the role of $\mathrm{Fe}^{3+}$ in acceleration oxidation (indirect mechanism). At the same time, in the three types of solution, the oxidation peak area of the galvanic pair is larger than that of arsenopyrite, which indicates that the galvanic effect accelerates the oxidation of arsenopyrite.

The corrosion behavior of the three electrodes in all investigated solutions was further studied using the Tafel curve (Figure 4). The calculated Tafel curve data are listed in Table 2.

Table 2. The calculated Tafel curve data of pyrite, arsenopyrite, and the galvanic pair in the investigated solutions (C.C.: Cathode Current; A.C.: Anode Current; $\mathrm{i}_{\text {corr }}$ : Corrosion current; $\mathrm{E}_{\text {corr }}$ : Corrosion potential).

\begin{tabular}{|c|c|c|c|c|c|c|c|c|c|c|c|c|}
\hline \multirow[b]{2}{*}{ Solution } & \multicolumn{4}{|c|}{ Pyrite } & \multicolumn{4}{|c|}{ Arsenopyrite } & \multicolumn{4}{|c|}{ Galvanic Pair } \\
\hline & $\begin{array}{l}\text { C.C } \\
(\lg \text { i) }\end{array}$ & $\begin{array}{l}\text { A.C } \\
\text { (lg i) }\end{array}$ & $\begin{array}{c}i_{\text {corr }} \\
\left(10^{-6} A\right)\end{array}$ & $\begin{array}{l}E_{\text {corr }} \\
\text { (V) }\end{array}$ & $\begin{array}{l}\text { C.C } \\
\text { (lg i) }\end{array}$ & $\begin{array}{l}\text { A.C } \\
(\lg \text { i) }\end{array}$ & $\begin{array}{c}i_{\text {corr }} \\
\left(10^{-6} \mathrm{~A}\right)\end{array}$ & $\begin{array}{l}E_{\text {corr }} \\
\text { (V) }\end{array}$ & $\begin{array}{l}\text { C.C } \\
(\lg \text { i) }\end{array}$ & $\begin{array}{l}\text { A.C } \\
(\lg \text { i) }\end{array}$ & $\begin{array}{c}i_{\text {corr }} \\
\left(10^{-6} A\right)\end{array}$ & $\begin{array}{l}E_{\text {corr }} \\
\text { (V) }\end{array}$ \\
\hline Sulfuric acid & -5.61 & -5.59 & 3.83 & 0.56 & -5.37 & -4.81 & 14.1 & 0.22 & -5.00 & -4.54 & 33.8 & 0.20 \\
\hline Ferric ion & -4.93 & -4.96 & 1.46 & 0.63 & -3.85 & -3.71 & 260 & 0.40 & -3.67 & -3.57 & 390 & 0.39 \\
\hline HQ0211 strain & -4.83 & -4.91 & 18.8 & 0.64 & -3.92 & -3.40 & 160 & 0.46 & -3.40 & -3.23 & 467 & 0.45 \\
\hline
\end{tabular}

As shown in Figure 4, the corrosion potential of the galvanic pair is similar to that of arsenopyrite $(0.22,0.40,0.46)$ but very different from that of pyrite $(0.56,0.63,0.64$ in three investigated solutions respectively), which indicates that the corrosion of the galvanic pair occurs at a potential similar to that of arsenopyrite. The slight decrease in the current marked in Figure 4 by a red circle is due to the oxidation of iron in the arsenopyrite, which is characteristic of arsenopyrite oxidation (pyrite does not have this characteristic) $[26,28]$. This is the same as the characteristic of the galvanic effect (an anodic reaction occurs first without changing the reaction process). It is also consistent with the results of the linear voltammetry analysis.

The acceleration of the anodic reaction due to the galvanic effect is reflected in the corrosion current. Table 2 shows that in the sulfuric acid, ferric ion, and HQ0211 strain solutions, the corrosion current of the galvanic pair was 2.40 times, 1.50 times, and 2.92 times that of arsenopyrite, respectively. The galvanic effect observably accelerates the oxidation of arsenopyrite. The limiting steps of the oxidation of arsenopyrite by the cathodic process can also be seen in Table 2 . The increase in the cathodic current of arsenopyrite is larger than that in the anodic current when coupled with pyrite, which is due to the enhancement of the electron donation capability of the slightly negative pyrite.

The rate determining step and the reaction mechanism of the electrode system can be illustrated by electrochemical impedance spectroscopy (EIS). Nyquist plots of the galvanic pair and arsenopyrite in the three investigated solutions are shown in Figure 5. The shape of the Nyquist plot of the galvanic pair is very similar to that of arsenopyrite in the three investigated solutions with the same initial E. This shows that the reaction mechanisms of the galvanic pair and arsenopyrite alone are similar under the same potential. 


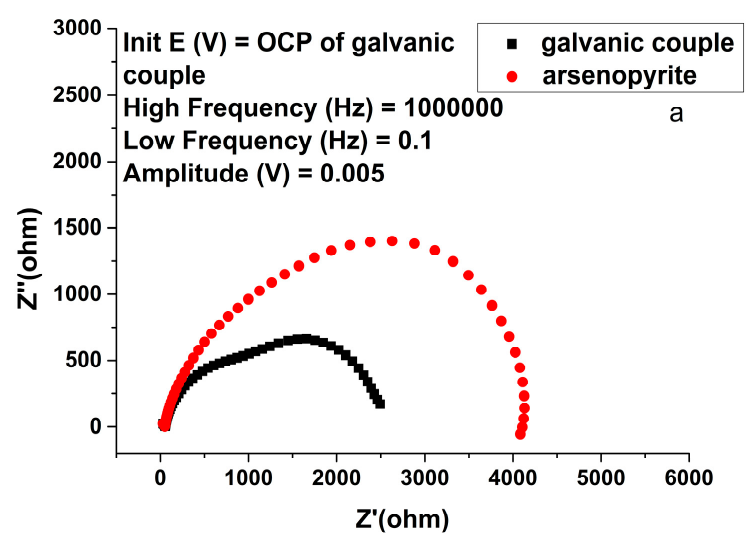

(a)

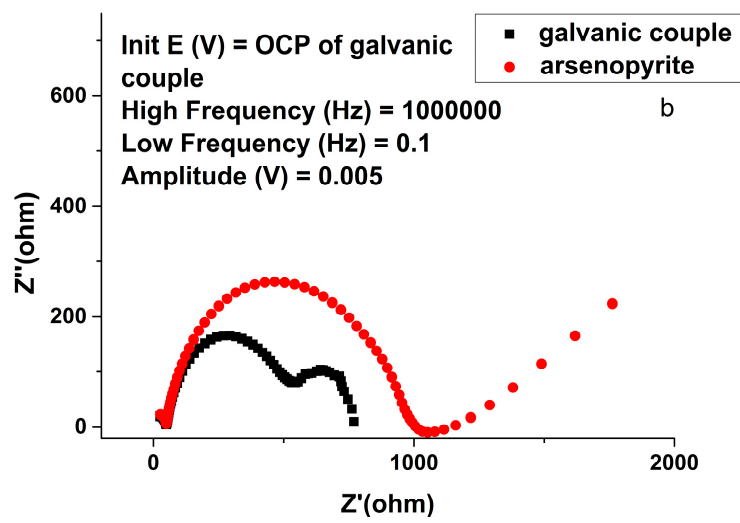

(b)

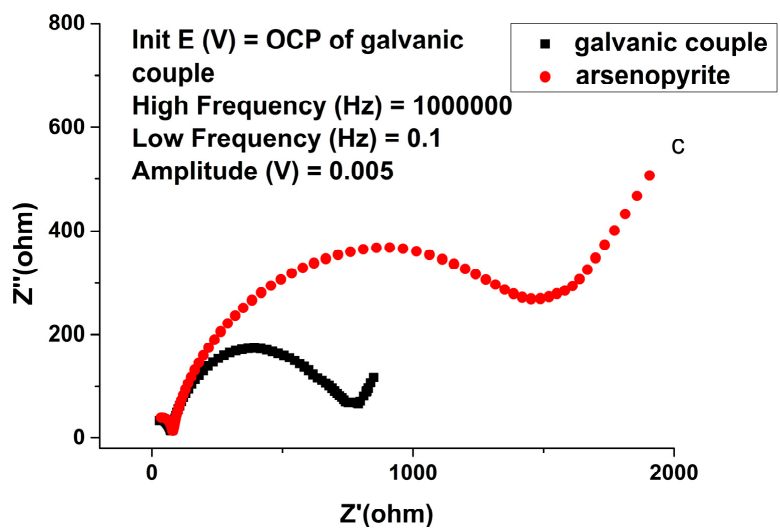

(c)

Figure 5. Nyquist plots of the galvanic pair and arsenopyrite in sulfuric acid (a), ferric ion (b), and HQ0211 strain solutions (c).

To further fit the data, this paper improved upon the analog circuit created by Deng et al. [31] in the sulfuric acid solution. The analog circuit and theory model are shown in Figure 6. A new oxidation resistance $R_{3}$ and interface $Q_{3}$ were added to the circuit. The resistance of the electrochemical reaction is parallel to the capacitance of the double layer. The solution resistance is connected in series with the parallel circuit of the electrode-electrolyte double-layer capacitance and the electrochemical reaction resistance. The initial oxidation resistance is connected in series with the parallel circuit of the surface film-electrolyte double-layer capacitance and the further oxidation resistance of the surface film. Furthermore, the second oxidation resistance is connected in series with the parallel circuit of the 
surface film-electrode capacitance and the further oxidation resistance of the surface film. Since the first layer of oxidation resistance disappears, we use the analog circuits from Deng et al. [31] in ferric ion and HQ0211 strain solutions.

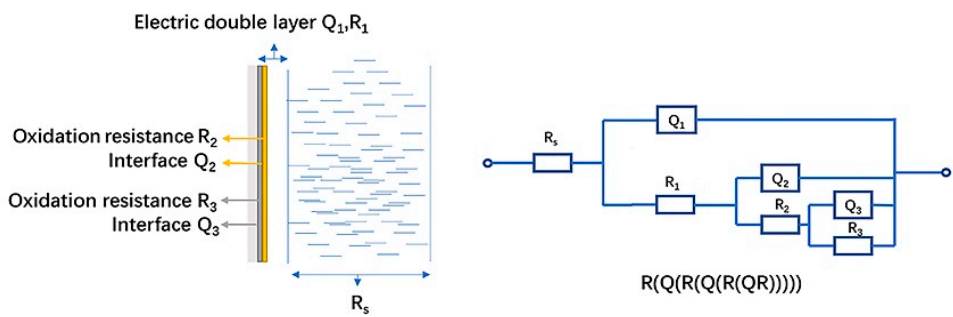

(a)

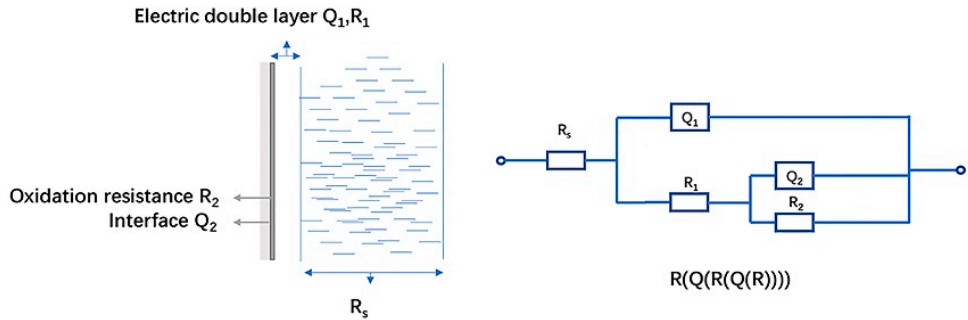

(b)

Figure 6. The theoretical model and analog circuit from electrochemical impedance spectroscopy (EIS) in the three investigated solutions: (a) analog circuit from EIS of the galvanic pair and arsenopyrite in sulfuric acid solution; and (b) the galvanic pair and arsenopyrite in ferric ion and HQ0211 strain solutions.

In the ferric ion solution and HQ0211 strain, Rs and R1 represent the solution resistance and the charge transfer resistance during arsenopyrite oxidation, respectively. Q1 and Q2 correspond to the double-layer capacitances between electrode/electrolyte interfaces and surface layer ( $\mathrm{S}^{0}$ layer)/electrolyte interfaces, respectively. R2 represents the charge transfer resistance during the oxidation of the surface layer. In the sulfuric acid solution, an additional passivation layer $\left(\mathrm{As}_{2} \mathrm{~S}_{2}\right)$ is formed after the reaction [27]. Rs and R1 represent the solution resistance and the charge transfer resistance during arsenopyrite oxidation. Q1, Q2, and Q3 correspond to the double-layer capacitances between electrode/electrolyte interfaces, surface layer $\left(\mathrm{As}_{2} \mathrm{~S}_{2}\right.$ layer) (Reaction (8))/surface layer $\left(S^{0}\right.$ layer) interface, and surface layer $\left(S^{0}\right.$ layer)/electrolyte interfaces, respectively. $\mathrm{R} 2$ and $\mathrm{R} 3$ represent the charge transfer resistance during the oxidation of the $S$ layer and surface layer, respectively.

$$
\mathrm{FeAsS} \rightarrow \mathrm{Fe}^{2+}+0.5 \mathrm{As}_{2} \mathrm{~S}_{2}+2 \mathrm{e}^{-}
$$

The fitting data and fitting errors are listed in Table 3. As shown in Table 3, the limiting step of the arsenopyrite oxidation reaction in a sulfuric acid solution is $R_{3}$ (charge transfer resistance during the oxidation of surface layer) and depends on whether arsenopyrite alone or the galvanic pair was used. The $R_{3}$ values of arsenopyrite and the galvanic pair are 2398 and $1475 \Omega \cdot \mathrm{cm}^{2}$, respectively. The galvanic effect can reduce the $R_{3}$ value to accelerate the oxidation of arsenopyrite. In ferric ion and HQ0211 strain solutions, the limiting step of arsenopyrite oxidation is $R_{2}$ (charge transfer resistance during the oxidation of the surface layer) for both arsenopyrite and the galvanic pair. The $R_{2}$ values of arsenopyrite and the galvanic pair are 898 and $498 \Omega \cdot \mathrm{cm}^{2}$, respectively, in the ferric ion solution. The $R_{2}$ values of arsenopyrite and the galvanic pair are 1153 and $809 \Omega \cdot \mathrm{cm}^{2}$, respectively, in the bacterial solution. The higher $\mathrm{R}_{2}$ value in the bacterial solution may be due to the toxic effect of arsenopyrite on bacteria. This results in bacteria carrying ferric ions, which tend not to adsorb on the surface of 
arsenopyrite or the galvanic pair. Apart from this, the galvanic effect can accelerate arsenopyrite oxidation by reducing the value of $R_{2}$. Therefore, the galvanic effect can accelerate the oxidation of arsenopyrite and determine the rate-limiting step of the reaction.

Table 3. Fitting data and fitting errors of the investigated electrochemical impedance spectroscopy (EIS) data.

\begin{tabular}{|c|c|c|c|c|c|c|c|c|c|}
\hline Solution & Electrode & $\mathrm{R}_{\mathrm{s}} / \Omega \cdot \mathrm{cm}^{2}$ & $\begin{array}{c}\mathrm{Y}_{\mathrm{o}, 1} / 10^{-9} \\
\mathrm{~S} \cdot \mathrm{s}^{\mathrm{n}} \cdot \mathrm{cm}^{-2} \\
\text { (n) }\end{array}$ & $\mathrm{R}_{1} / \Omega \cdot \mathrm{cm}^{2}$ & $\begin{array}{c}\mathrm{Y}_{0,2} / 10^{-5} \\
\mathrm{~S} \cdot \mathrm{s}^{\mathrm{n}} \cdot \mathrm{cm}^{-2} \\
\text { (n) }\end{array}$ & $\mathrm{R}_{2} / \Omega \cdot \mathrm{cm}^{2}$ & $\begin{array}{c}\mathrm{Y}_{\mathrm{o}, 3} / 10^{5} \\
\mathrm{~S} \cdot \mathrm{s}^{\mathrm{n}} \cdot \mathrm{cm}^{-2}\end{array}$ & $\mathrm{R}_{3} / \Omega \cdot \mathrm{cm}^{2}$ & $\begin{array}{c}\text { Fitting } \\
\text { Error } \\
\chi^{2} / 10^{-3}\end{array}$ \\
\hline \multirow{2}{*}{$\begin{array}{l}\text { Sulfuric } \\
\text { acid }\end{array}$} & Arsenopyrite & 7.958 & 5.33 & 42.44 & 1.059 & 1769 & 2.674 & 2398 & 0.23 \\
\hline & Galvanic pair & 6.408 & 8.49 & 48.21 & 1.635 & 1002 & 12.97 & 1475 & 0.69 \\
\hline \multirow{2}{*}{$\begin{array}{l}\text { Ferric } \\
\text { ion }\end{array}$} & Arsenopyrite & 1.209 & 3.65 & 45.93 & 1.183 & 898 & - & - & 0.98 \\
\hline & Galvanic pair & 9.284 & 6.5 & 39.41 & 1.369 & 483 & - & - & 0.74 \\
\hline \multirow{2}{*}{$\begin{array}{l}\text { HQ0211 } \\
\text { strain }\end{array}$} & Arsenopyrite & 2.337 & 2.69 & 75.23 & 1.25 & 1153 & - & - & 0.81 \\
\hline & Galvanic pair & 2.93 & 3.06 & 64.66 & 3.31 & 809 & - & - & 2.09 \\
\hline
\end{tabular}

\subsection{DFT Calculations}

The calculation errors are listed in Table 4. Among all lattice parameters, the maximum calculation error of pyrite was $0.01 \%$, and that of arsenopyrite was $0.05 \%$, which meets the error requirement of Generalized Gradient Approximation (GGA)-Perdew-Wang (PW91). The crystal structure and highest occupied molecular orbital (HOMO) (green and yellow iso surface) of pyrite, arsenopyrite, and $\mathrm{Fe}^{2+}$ and the lowest unoccupied molecular orbital (LUMO) of $\mathrm{Fe}^{3+}$ are shown in Figure 7a-d, respectively. The HOMO orbitals of the arsenopyrite and pyrite crystals are distributed around the iron atoms, and the $\mathrm{Fe}^{2+}$ and $\mathrm{Fe}^{3+}$ orbital hybridization modes are different. The process of chemical reaction is actually the same as the process of electron migration from the HOMO of the reductant to the LUMO of the oxidant. The transfer of electrons during the oxidation of pyrite by ferric ions is shown in Reaction (3). The HOMO value of arsenopyrite $(-0.180)$ is higher than that of pyrite $(-0.220)$. When arsenopyrite and pyrite co-exist, the final electron donor is arsenopyrite. This is why the oxidation behavior of the galvanic pair is characterized by arsenopyrite oxidation behavior. However, because the HOMO of pyrite is closer to the LUMO of $\mathrm{Fe}^{3+}(-0.241)$ than to the HOMO of arsenopyrite, it is easier for electrons to migrate from arsenopyrite to the pyrite surface than for electrons to migrate from the pyrite surface to $\mathrm{Fe}^{3+}$. Therefore, the presence of pyrite accelerates the oxidation of arsenopyrite in the galvanic pair.

Table 4. Calculation errors for pyrite and arsenopyrite.

\begin{tabular}{ccccccc}
\hline Lattice Parameter & $\begin{array}{c}\mathrm{A} \\
\text { (Angstrom) }\end{array}$ & $\begin{array}{c}\mathbf{B} \\
\text { (Angstrom) }\end{array}$ & $\begin{array}{c}\mathbf{C} \\
\text { (Angstrom) }\end{array}$ & $\boldsymbol{\alpha}\left(^{\circ}\right)$ & $\beta\left(^{\circ}\right)$ & $\gamma\left({ }^{\circ}\right)$ \\
\hline $\begin{array}{c}\text { Calculated pyrite lattice } \\
\text { parameter }\end{array}$ & 5.411 & 5.411 & 5.411 & 90 & 90 & 90 \\
$\begin{array}{c}\text { Calculation errors for pyrite } \\
\begin{array}{c}\text { Calculated arsenopyrite } \\
\text { lattice parameter }\end{array}\end{array}$ & $0.01 \%$ & $0.01 \%$ & $0.01 \%$ & $0 \%$ & $0 \%$ & $0 \%$ \\
$\begin{array}{c}\text { Calculation errors for } \\
\text { arsenopyrite }\end{array}$ & 9.46 & 5.63 & 6.39 & 89.9 & 89.7 & 89.9 \\
\hline
\end{tabular}




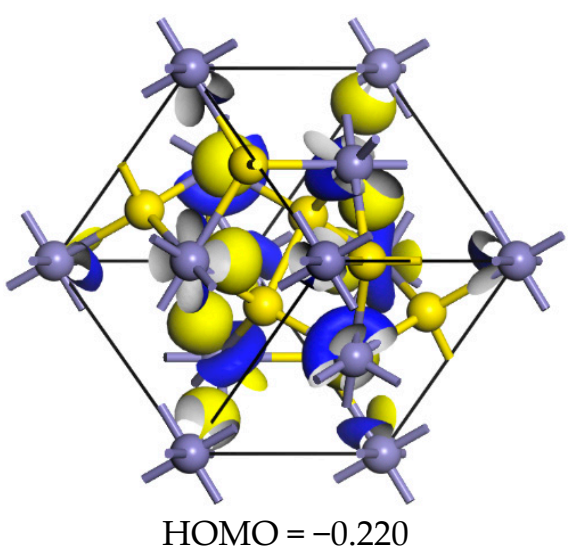

(a)

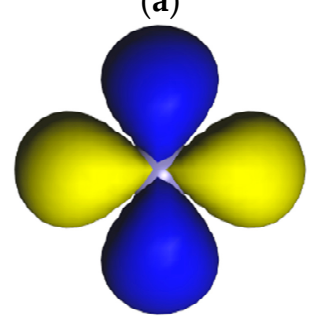

$\mathrm{HOMO}=-0.239$

(c)

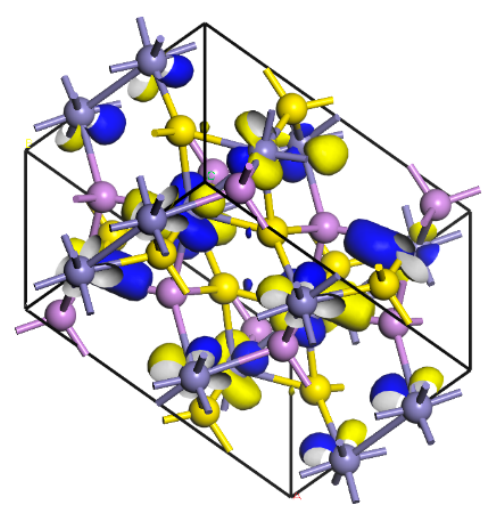

$\mathrm{HOMO}=-0.180$

(b)

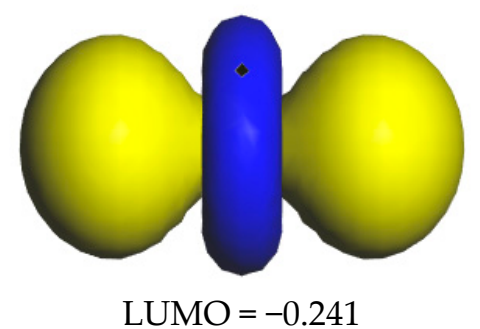

(d)

Figure 7. Crystal structure and highest occupied molecular orbital (HOMO) (green and yellow iso surface) of pyrite (a), arsenopyrite (b), and $\mathrm{Fe}^{2+}(\mathbf{c})$ and lowest unoccupied molecular orbital (LUMO) of $\mathrm{Fe}^{3+}$ (d) (blue ball for Fe atom, yellow ball for $\mathrm{S}$ atom, and purple ball for As atom).

\section{Conclusions}

By conducting electrochemical and DFT studies of three types of electrodes (pyrite, arsenopyrite, and a galvanic pair), the galvanic effect of pyrite and arsenopyrite in sulfuric acid, ferric ion, and HQ0211 strain solutions was determined to improve our understanding of the pyrite/arsenopyrite galvanic effect. The following conclusions were drawn:

1. After a detailed comparison, the corrosion process of the pyrite/arsenopyrite galvanic pair is similar to that of arsenopyrite, which is clearly supported by electrochemical data.

2. EIS models of pyrite/arsenopyrite galvanic pair were established as $R(Q(R(Q(R(Q R)))))$ and $\mathrm{R}(\mathrm{Q}(\mathrm{R}(\mathrm{Q}(\mathrm{R}))))$ and the physical meaning was clearly indicated.

3. The mechanism of the galvanic effect that accelerates arsenopyrite corrosion by increasing the cathode and anode currents as well as the charge transfer resistance during the oxidation of the surface layer of the reaction was proposed.

4. The quantum mechanics perspective of pyrite/arsenopyrite galvanic effect was provided. The calculated results show that the oxidation behavior of the galvanic pair is characterized by arsenopyrite oxidation behavior, and the presence of pyrite accelerates the oxidation of arsenopyrite in the galvanic pair.

Author Contributions: J.-N.X. and H.-Y.Y. were responsible for experimental research and writing. J.-N.X., W.-G.S., P.-C.M., L.-S.L., G.-M.C. and H.-Y.Y. discussed the results and evaluated the data.

Funding: The authors acknowledge financial support from the National Key R\&D Program of China (No. 2018YFC1902002) and the Special Funds for the National Natural Science Foundation of China (No. U1608254).

Acknowledgments: This research is supported by Northeastern University Testing Center and the Shandong Zhaojin Group Co., Ltd. The authors wish to acknowledge Xue-Min Qiu, Guo-Bao Chen, Linlin Tong, and Zhenan Jin for their technical and laboratory assistance. The assistance on Material Studio was provided by Jianhua Chen of Guangxi University. 
Conflicts of Interest: The authors declare no conflict of interest.

\section{References}

1. Li, S.N.; Ni, P.; Bao, T.; Li, C.Z.; Xiang, H.L.; Wang, G.G.; Huang, B.; Chi, Z.; Dai, B.Z.; Ding, J.Y. Geology, fluid inclusion, and stable isotope systematics of the Dongyang epithermal gold deposit, Fujian Province, southeast China: Implications for ore genesis and mineral exploration. J. Geochem. Explor. 2018, 195, 16-30. [CrossRef]

2. Mansurov, Y.N.; Miklin, Y.A.; Miklin, N.A.; Nikol'Skii, A.V. Methods and Equipment for Breaking Down Gold-Containing Concentrates from Lean Ores and Mining Industry Waste. Metallurgist 2018, 62, $169-175$. [CrossRef]

3. Kravtsova, R.G.; Tauson, V.L.; Nikitenko, E.M. Modes of Au, Pt, and Pd occurrence in arsenopyrite from the Natalkinskoe deposit, NE Russia. Geochem. Int. 2015, 53, 964-972. [CrossRef]

4. Khishgee, C.; Akasaka, M.; Ohira, H.; Sereenen, J. Gold Mineralization of the Gatsuurt Deposit in the North Khentei Gold Belt, Central Northern Mongolia. Resour. Geol. 2014, 64, 1-16. [CrossRef]

5. Komnitsas, C.; Pooley, F. Mineralogical characteristics and treatment of refractory gold ores. Miner. Eng. 1989, 2, 449-457. [CrossRef]

6. Rajasekar, A. Bio-oxidation and bio-cyanidation of refractory mineral ores for gold extraction: A review. Crit. Rev. Environ. Sci. Technol. 2015, 45, 1611-1643. [CrossRef]

7. Kaksonen, A.H.; Perrot, F.; Morris, C.; Rea, S.; Benvie, B.; Austin, P.; Hackl, R. Evaluation of submerged bio-oxidation concept for refractory gold ores. Hydrometallurgy 2014, 141, 117-125. [CrossRef]

8. Anjum, F.; Shahid, M.; Akcil, A. Biohydrometallurgy techniques of low grade ores: A review on black shale. Hydrometallurgy 2012, 117-118, 1-12. [CrossRef]

9. Komnitsas, C.; Pooley, F. Bacterial oxidation of an arsenical gold sulphide concentrate from Olympias, Greece. Miner. Eng. 1990, 3, 295-306. [CrossRef]

10. Smith, E.E.; Shumate, K.S.; Singer, P.C.; Stumm, W. Direct Oxidation by Adsorbed Oxygen during Acidic Mine Drainage. Science 1970, 169, 98. [CrossRef]

11. Breed, A.W.; Glatz, A.; Hansfor, G.S.; Harrison, S.T.L. The effect of As(III) and As(V) on the batch bioleaching of a pyrite-arsenopyrite concentrate. Miner. Eng. 1996, 9, 1235-1252. [CrossRef]

12. Yu, Y.; Zhu, Y.; Gao, Z.; Gammons, C.H.; Li, D. Rates of arsenopyrite oxidation by oxygen and Fe(III) at pH 1.8-12.6 and $15-45^{\circ} \mathrm{C}$. Environ. Sci. Technol. 2007, 41, 6460-6464. [CrossRef] [PubMed]

13. Moses, C.O.; Nordstrom, D.K.; Herman, J.S.; Aaron, L. Aqueous pyrite oxidation by dissolved oxygen and by ferric iron. Geochim. Cosmochim. Acta 1987, 51, 1561-1571. [CrossRef]

14. Mehta, A.P.; Murr, L.E. Fundamental studies of the contribution of galvanic interaction to acid-bacterial leaching of mixed metal sulfides. Hydrometallurgy 1983, 9, 235-256. [CrossRef]

15. Urbano, G.; Reyes, V.E.; Veloz, M.A.; GonzáLez, I. Pyrite-Arsenopyrite Galvanic Interaction and Electrochemical Reactivity. J. Phys. Chem. C 2008, 112, 10453-10461. [CrossRef]

16. Saavedra, A.; García-Meza, J.V.; Cortón, E.; González, I. Understanding galvanic interactions between chalcopyrite and magnetite in acid medium to improve copper (Bio)Leaching. Electrochim. Acta 2018, 265, 569-576. [CrossRef]

17. Santos, E.C.D.; Lourenço, M.P.; Pettersson, L.G.M.; Duarte, H.A. Stability, Structure, and Electronic Properties of the Pyrite/Arsenopyrite Solid-Solid Interface-A DFT Study. J. Phys. Chem. C 2017, 121, 8042-8051. [CrossRef]

18. Deng, S.; Gu, G.; He, G.; Li, L. Catalytic effect of pyrite on the leaching of arsenopyrite in sulfuric acid and acid culture medium. Electrochim. Acta 2018, 263, 8-16. [CrossRef]

19. Huai, Y.; Plackowski, C.; Peng, Y. The galvanic interaction between gold and pyrite in the presence of ferric ions. Miner. Eng. 2018, 119, 236-243. [CrossRef]

20. Qin, W.Q.; Wang, X.J.; Li-Yuan, M.A.; Jiao, F.; Liu, R.Z.; Gao, K. Effects of galvanic interaction between galena and pyrite on their flotation in the presence of butyl xanthate. Trans. Nonferrous Met. Soc. China 2015, 25, 3111-3118. [CrossRef]

21. Delley, B. From molecules to solids with the $\mathrm{DMol}^{3}$ approach. J. Chem. Phys. 2000, 113, 7756-7764. [CrossRef] 
22. Perdew, J.P.; Chevary, J.A.; Vosko, S.H.; Jackson, K.A.; Pederson, M.R.; Singh, D.J.; Fiolhais, C. Atoms, molecules, solids, and surfaces: Applications of the generalized gradient approximation for exchange and correlation. Phys. Rev. B 1993, 46, 6671-6687. [CrossRef]

23. Vanderbilt, D. Soft self-consistent pseudopotentials in a generalized eigenvalue formalism. Phys. Rev. B 1990, 41, 7892. [CrossRef]

24. Bayliss, P. Crystal chemistry and crystallography of some minerals within the pyrite group. Am. Miner. 1989, 74, 1168-1176.

25. Buerger, M. The symmetry and crystal structure of the minerals of the arsenopyrite group. Z. Krist. Cryst. Mater. 1936, 95, 83-113. [CrossRef]

26. Rohwerder, T.; Gehrke, T.; Kinzler, K.; Sand, W. Bioleaching review part A: Progress in bioleaching: Fundamentals and mechanisms of bacterial metal sulfide oxidation. Appl. Microbiol. Biotechnol. 2003, 63, 239. [CrossRef] [PubMed]

27. Sand, W.; Gehrke, T. Extracellular polymeric substances mediate bioleaching/biocorrosion via interfacial processes involving iron(III) ions and acidophilic bacteria. Res. Microbiol. 2006, 157, 49-56. [CrossRef]

28. Deng, S.; Gu, G.; Xu, B.; Li, L.; Wu, B. Surface characterization of arsenopyrite during chemical and biological oxidation. Sci. Total Environ. 2018, 626, 349. [CrossRef]

29. Corkhill, C.L.; Vaughan, D.J. Arsenopyrite oxidation-A review. Appl. Geochem. 2009, 24, $2342-2361$. [CrossRef]

30. Yang, H.Y.; Liu, Q.; Chen, G.B.; Tong, L.L.; Ali, A. Bio-dissolution of pyrite by Phanerochaete chrysosporium. Trans. Nonferrous Met. Soc. China 2018, 28, 766-774. [CrossRef]

31. Deng, S.; Gu, G. An electrochemical impedance spectroscopy study of arsenopyrite oxidation in the presence of Sulfobacillus thermosulfidooxidans. Electrochim. Acta 2018, 287, 106-114. [CrossRef]

(C) 2019 by the authors. Licensee MDPI, Basel, Switzerland. This article is an open access article distributed under the terms and conditions of the Creative Commons Attribution (CC BY) license (http://creativecommons.org/licenses/by/4.0/). 